\title{
THE AMINO ACID CONTENT OF HUMAN CEREBROSPINAL FLUID IN NORMAL INDIVIDUALS AND IN MENTAL DEFECTIVES *
}

\author{
By THOMAS L. PERRY AND RICHARD T. JONES † \\ (From the Division of Chemistry and Chemical Engineering (Contribution no. 2660), California \\ Institute of Technology, Pasadena, Calif. and Pacific State Hospital, Pomona, Calif.)
}

(Submitted for publication January 12, 1961 ; accepted April 6, 1961)

This investigation of the concentrations of amino acids in human cerebrospinal fluid (CSF) was stimulated by curiosity as to the mechanism of mental defect in various genetically determined diseases. Studies of serum amino acids and of the pattern of their urinary excretion have in recent years made significant contributions to an understanding of the biochemical etiology of some types of mental deficiency. But it seems likely that in some conditions abnormalities in the biochemistry of the central nervous system may be overlooked if studies are confined to those metabolites excreted in the urine or to those circulating in the blood. Because the CSF is not merely an ultrafiltrate formed by way of the choroid plexuses, but is the product of an exchange between the blood and the central nervous system, examination of this fluid may sometimes yield important clues to deranged cerebral metabolism. In the recently discovered disorder argininosuccinicaciduria (1), for instance, the concentration of argininosuccinic acid has been found to be greater in CSF than in plasma, thus suggesting that the brain rather than some other organ is the site of the metabolic error.

Recent reports concerning the amino acids found in normal human CSF are confusing. Different investigators have found as few as seven to as many as 21 amino acids present. Using paper chromatographic techniques, quantitative estimation of the amino acids in CSF has been attempted by Torre, Scarzella and Zanalda (2), Porcellati and Kemali (3), Walker, Telles and Pastore (4), and by Logothetis (5). Huisman (6) made use of quantitative column chromatography for the determination of amino acids in CSF. Glutamine concentrations in CSF have been estimated by

\footnotetext{
* Supported by a grant from the Ford Foundation.

$\dagger$ This investigation was carried out during tenure of a Postdoctoral Fellowship from the United States Public Health Service.
}

hydrolysis of glutamine to ammonia, and subsequent colorimetric determination of ammonia (7-9). The most recent studies by Knauff, Zickgraf and Mialkowsky $(10,11)$ have used combined high voltage paper electrophoresis and paper chromatography for the qualitative identification of amino acids in CSF. They found 25 ninhydrin-positive substances, of which they were able to identify 21 . There has been a lack of agreement among investigators, in particular concerning the normal occurrence of $\gamma$-aminobutyric acid, cystine, proline, and methionine in CSF.

Most studies to date have failed to show differences between the amino acid pattern of normal CSF and of that found in neurological disease. Exceptions are the reports of high CSF levels of argininosuccinic acid in argininosuccinicaciduria (1), of phenylalanine in phenylketonuria (12), of glutamine in hepatic coma (7-9), and of aspartic acid in hereditary cerebellar ataxia (13).

The development of the automatic amino acid analyzer (14) has made possible more accurate and rapid measurement of a number of ninhydrinpositive substances in physiological fluids. In the present study this instrument was used to determine the concentrations of amino acids in normal pooled CSF. A preliminary investigation was also made of possible differences in amino acids in the CSF of patients suffering from a variety of genetically determined diseases involving mental defect.

\section{MATERIALS AND METHODS}

Pooled CSF from adults was used in the study of amino acid concentrations in normal individuals. Ideally it would have been desirable to study individual CSF specimens, and to obtain the fluid from children, since most of the mental defectives studied were children; but there seemed no justification for collecting CSF from normal children, nor for collecting sufficient fluid from individual normal adults to make possible individual amino acid determinations. Accordingly, three pools of 
TABLE I

Mental defectives whose CSF was studied

\begin{tabular}{|c|c|c|c|c|c|}
\hline $\begin{array}{l}\text { Patient } \\
\text { no. }\end{array}$ & Age & Sex & $\begin{array}{l}\text { No. of } \\
\text { lumbar } \\
\text { punctures } \\
\text { to secure } \\
\text { specimen }\end{array}$ & Clinical diagnosis & Remarks \\
\hline & $y r s$ & & & & \\
\hline 1 & 10 & M & 2 & Phenylketonuria /siblinge & \\
\hline 2 & $11 \frac{1}{2}$ & $\mathrm{~F}$ & 2 & Phenylketonuria & \\
\hline 3 & $26^{2}$ & $\mathrm{~F}$ & 2 & Phenylketonuria & \\
\hline 4 & 2 & $\mathrm{M}$ & 2 & Tay-Sachs disease & \\
\hline 5 & $2 \frac{1}{2}$ & $\mathrm{M}$ & 2 & Tay-Sachs disease & \\
\hline 6 & $2 \frac{1}{2}$ & M & 2 & Tay-Sachs disease & \\
\hline 7 & 54 & $\mathbf{M}$ & 1 & Huntington's chorea & Symptoms for $1 \frac{1}{4}$ years \\
\hline 8 & 53 & $\mathrm{~F}$ & 1 & Huntington's chorea & Symptoms for 14 years \\
\hline 9 & 54 & $\mathrm{~F}$ & 1 & Huntington's chorea & Symptoms for 17 years \\
\hline 10 & $12 \frac{1}{3}$ & $\mathbf{M}$ & 2 & Hurler's syndrome* & \\
\hline 11 & $14 \frac{1}{2}$ & M & 2 & Hurler's syndrome* Siblings & \\
\hline 12 & $10 \frac{1}{2}$ & M & 2 & Hurler's syndrome* & \\
\hline 13 & $13 \frac{1}{2}$ & $\mathbf{M}$ & 1 & Tuberous sclerosis & \\
\hline 14 & $19 \frac{1}{3}$ & $\mathrm{~F}$ & 2 & Tuberous sclerosis & \\
\hline 15 & $8 \frac{1}{2}$ & $\mathrm{~F}$ & 2 & Mongolism & \\
\hline 16 & $12^{2}$ & $\mathrm{M}$ & 2 & Mongolism & \\
\hline 17 & 16 & $\mathrm{M}$ & 2 & Schilder's disease & \\
\hline 18 & $4 \frac{1}{3}$ & M & 1 & $\begin{array}{l}\text { Cerebro-oculo-renal } \\
\text { disease }\end{array}$ & \\
\hline
\end{tabular}

* No corneal infiltration.

CSF were collected from young women in labor at the time of administering spinal anesthesia just prior to delivery. The subjects were not necessarily in the postabsorptive state. Three to five $\mathrm{ml}$ of CSF was obtained by lumbar puncture from each subject, and each of the three pooled specimens contained fluid from 10 to 15 subjects. CSF specimens which were bloody were discarded and not added to the pooled CSF. The pooled $\mathrm{CSF}$ was kept frozen at $-20^{\circ} \mathrm{C}$ until used.

CSF specimens were obtained from 18 mentally defective patients by lumbar puncture. These patients also were not necessarily in the postabsorptive state. Fluid specimens which were bloody were discarded, and CSF was frozen immediately and kept at $-20^{\circ} \mathrm{C}$ until used. In 5 patients a single CSF specimen was studied, while in the remaining 13 patients two specimens were obtained on separate occasions and were then pooled. This was necessary because approximately $20 \mathrm{ml}$ of fluid is required for accurate determination of all amino acids present, and it seemed unwise to withdraw this volume of fluid on one occasion from a child. The genetically determined conditions studied were: phenylketonuria, Tay-Sachs disease, Hurler's syndrome (gargoylism), Huntington's chorea, mongolism, tuberous sclerosis, Schilder's disease, and the cerebro-oculo-renal disease of Lowe (15). Table I summarizes the pertinent clinical data for the patients studied.

CSF specimens were deproteinized by ultrafiltration through a cellophane membrane at $5^{\circ} \mathrm{C}$ over a period of 24 to 36 hours. The pooled CSF specimens were deproteinized after several months' storage at $-20^{\circ} \mathrm{C}$. Some of the individual CSF specimens from mentally defective patients were deproteinized immediately, while others were first stored at $-20^{\circ} \mathrm{C}$ for as long as 3 months. After being deproteinized, specimens were desalted electrolytically in an electric desalter, ${ }^{1}$ using a maximum current of 0.6 a. Each specimen was then divided into 3 fractions, and these were individually taken to dryness under vacuum on a rotating evaporator with the use of gentle heat (not over $40^{\circ} \mathrm{C}$ ). The 2 larger fractions, usually representing 9 or $10 \mathrm{ml}$ of original CSF each, were applied to the $150-\mathrm{cm}$ and $50-\mathrm{cm}$ columns, respectively, of the automatic amino acid analyzer. The third fraction, usually representing $2.5 \mathrm{ml}$ of original $\mathrm{CSF}$, was hydrolyzed with $2 \mathrm{~N} \mathrm{HCl}$ at $110^{\circ} \mathrm{C}$ for 2 hours in an evacuated sealed tube, and was applied to the $150 \cdot \mathrm{cm}$ column of the analyzer.

The analyses were performed with a Spinco automatic amino acid analyzer, model 120 , under the conditions described by Spackman, Stein and Moore (14). The $30^{\circ}$ to $50^{\circ} \mathrm{C}$ systems were employed for the determination of amino acids and derivatives in the unhydrolyzed portions of each CSF specimen. The hydrolyzed portions were analyzed only on the neutral and acidic $(150-\mathrm{cm})$ column, and most of the latter analyses were carried out using the $50^{\circ} \mathrm{C}$ system.

Identification of the ninhydrin-positive components found in CSF was based upon comparison with ion exchange chromatograms prepared from solutions of authentic amino acids and related compounds. In addition, two-dimensional paper chromatography carried out in this laboratory prior to this investigation had demonstrated the presence in pooled human CSF of the following amino acids: alanine, arginine, aspartic acid, glutamic acid, glutamine, glycine, histidine, isoleucine-leucine,

1 Research Specialties Co., 200 S. Garrard Blvd., Richmond, Calif. 
lysine, phenylalanine, serine, taurine, threonine, tryptophan, tyrosine, and valine.

Calculations of the amounts of amino acids present in each analyzed specimen of CSF were made in the standard manner as described for the automatic recording equipment (14). With this technique it is possible to measure amino acids with a precision in the order of $100 \pm 3$ per cent for loads of 0.1 to $3.0 \mu$ mole of each amino acid. Color values for the common amino acids were based on analyses of standard amino acid solutions supplied by the Spinco Company. Color values for amino acids and related compounds not present in the Spinco standards (i.e., taurine, urea, citrulline, $\alpha$-amino$n$-butyric acid, cystathionine, ornithine and ethanolamine) were estimated by using the color values given by Spackman and associates (14), corrected by multiplying them by the ratio of the leucine color value determined for the present instrument to that reported for leucine by the above investigators. All unidentified compounds present in CSF were calculated as if they were leucine, using the ninhydrin color value of leucine.
In addition to the analysis of each CSF specimen on the automatic amino acid analyzer, 2 of the 3 pooled specimens of normal CSF were chromatographed onedimensionally on Whatman no. 1 paper in isopropanol: concentrated ammonia: water $(8: 1: 1)$. The sheets were developed with $p$-dimethylaminocinnamaldehyde, and the tryptophan spots which were detected were compared visually with graded mounts of authentic tryptophan which had been chromatographed simultaneously. In this manner the tryptophan content of these specimens was estimated, since this amino acid was difficult to measure in eluates from the amino acid analyzer. The quantities of CSF obtained from the defective patients were insufficient to permit estimation of tryptophan by this technique.

\section{RESULTS}

The concentrations of the amino acids found in the three pools of CSF from normal adults as well as in the individual fluids from 18 mental defectives

TABLE II

Amino acid content of normal pooled CSF

\begin{tabular}{|c|c|c|c|c|c|}
\hline Amino acid & Pool A & Pool B & Pool C & Mean & Mean \\
\hline & \multicolumn{2}{|c|}{ umoles per $10 \mathrm{ml}$} & \multicolumn{2}{|c|}{ umoles per $10 \mathrm{ml}$} & $\begin{array}{l}m g \text { per } \\
100 \mathrm{ml}\end{array}$ \\
\hline Unknown no. $1^{*}$ & 0.026 & 0.026 & 0.023 & 0.025 & \\
\hline Unknown no. $2^{*}$ & 0.028 & 0.016 & 0.055 & 0.033 & \\
\hline Unknown no. $3^{*}$ & 0.035 & 0.041 & 0.037 & 0.038 & \\
\hline Unknown no. $4^{*}$ & 0.056 & 0.064 & 0.039 & 0.053 & \\
\hline Unknown no. $5^{*}$ & 0 & $t$ & $\ddagger$ & $\ddagger$ & \\
\hline Taurine & 0.067 & 0.051 & 0.057 & 0.058 & 0.07 \\
\hline Urea & 26.82 & 22.46 & 29.76 & 26.35 & 15.81 \\
\hline Unknown no. 6* & $\dagger$ & 0.049 & 0.037 & 0.043 & \\
\hline Aspartic acid & 0.076 & 0.016 & $\ddagger$ & 0.031 & 0.04 \\
\hline Unknown no. 7* & 1.060 & 0.872 & 0.280 & 0.737 & \\
\hline Threonine & 0.487 & 0.437 & 0.513 & 0.479 & 0.57 \\
\hline Serine & 0.700 & 0.428 & 0.388 & 0.505 & 0.53 \\
\hline Asparagine & $<0.216$ & $<0.223$ & $<0.234$ & $<0.224$ & $<0.30$ \\
\hline Glutamine & 1.607 & 2.244 & 2.822 & 2.224 & 3.25 \\
\hline Proline & 0.042 & $\ddagger$ & 0 & 0.014 & 0.01 \\
\hline Glutamic acid & 0.088 & 0.090 & 0.048 & 0.075 & 0.11 \\
\hline Citrulline & $\ddagger$ & $\ddagger$ & 0 & $\ddagger$ & $\ddagger$ \\
\hline Glycine & 0.194 & 0.061 & 0.195 & 0.150 & 0.11 \\
\hline Alanine & 0.366 & 0.284 & 0.321 & 0.324 & 0.29 \\
\hline$\alpha$-Amino- $n$-butyric acid & 0.013 & 0.015 & 0 & 0.009 & 0.01 \\
\hline Valine & 0.138 & 0.169 & 0.118 & 0.142 & 0.17 \\
\hline Cystathionine & $\ddagger$ & $\ddagger$ & $\ddagger$ & $\ddagger$ & $\ddagger$ \\
\hline Methionine & 0.032 & 0.020 & 0.028 & 0.027 & 0.04 \\
\hline Isoleucine & 0.051 & 0.043 & 0.039 & 0.044 & 0.06 \\
\hline Leucine & 0.106 & 0.089 & 0.098 & 0.098 & 0.13 \\
\hline Tyrosine & 0.068 & 0.076 & 0.054 & 0.066 & 0.12 \\
\hline Phenylalanine & 0.094 & 0.087 & 0.084 & 0.088 & 0.15 \\
\hline Unknown no. 8* & $\S$ & 0.007 & 0 & 0.004 & \\
\hline Ornithine & $\S$ & 0.042 & 0.034 & 0.038 & 0.05 \\
\hline Ethanolamine & $\S$ & 0.191 & 0.066 & 0.129 & 0.08 \\
\hline Lysine & $\S$ & 0.206 & 0.134 & 0.170 & 0.25 \\
\hline Histidine & $\S$ & 0.148 & 0.109 & 0.129 & 0.20 \\
\hline Tryptophan & $\S$ & 0.012 & 0.015 & 0.014 & 0.03 \\
\hline Unknown no. 9* & $\ddot{\S}$ & 0.013 & $\ddagger$ & 0.007 & \\
\hline Arginine & $\ddot{\xi}$ & 0.105 & 0.092 & 0.099 & 0.17 \\
\hline
\end{tabular}

* Calculated as leucine-equivalents.

$\dagger$ Present on chromatogram in measurable amount, but technical failure prevented quantitation.

$\ddagger$ Present on chromatogram, but amount insufficient for quantitation.

$\S$ Measurement not attempted. 
TABLE III

Amino acid content of CSF of mental defectives (in $\mu$ moles $/ 10 \mathrm{ml}$ )

\begin{tabular}{|c|c|c|c|c|c|c|c|c|c|c|}
\hline \multirow[b]{2}{*}{ Amino acid } & \multirow{2}{*}{$\begin{array}{l}\text { Normal mean } \\
\text { (from Table II) }\end{array}$} & \multicolumn{3}{|c|}{ Phenylketonuria } & \multicolumn{3}{|c|}{ Tay-Sachs disease } & \multicolumn{3}{|c|}{ Huntington's chorea } \\
\hline & & 1 & 2 & 3 & 4 & 5 & 6 & 7 & 8 & 9 \\
\hline Unknown no. $1 *$ & 0.025 & 0.016 & 0.029 & 0.021 & 0.016 & 0.018 & 0.029 & 0.020 & 0.017 & 0.019 \\
\hline Unknown no. $2^{*}$ & 0.033 & $t$ & 0.047 & 0.011 & & 0.010 & 0.021 & 0.013 & 0.016 & 0.013 \\
\hline Unknown no. 3* & 0.038 & 0.019 & $t$ & $t$ & $t$ & 0.010 & $t$ & 0.025 & & $t$ \\
\hline Unknown no. $4^{*}$ & 0.053 & 0.056 & 0.042 & 0.038 & 0.038 & 0.050 & 0.028 & 0.062 & 0.044 & 0.036 \\
\hline Unknown no. 5* & $t$ & 0 & $t$ & 0 & 0 & 0 & 0 & 0 & & 0 \\
\hline Taurine & 0.058 & 0.061 & 0.065 & 0.059 & 0.040 & 0.036 & 0.045 & 0.064 & 0.058 & 0.070 \\
\hline Urea & 26.35 & 29.23 & 20.03 & 38.58 & 19.95 & 24.85 & 24.10 & 40.15 & 46.65 & 37.20 \\
\hline Unknown no. $6 *$ & 0.043 & 0.049 & 0 & 0.054 & 0.031 & 0.034 & 0.025 & 0.047 & 0.037 & 0.031 \\
\hline Aspartic acid & 0.031 & $t$ & + & 0.021 & 0.013 & 0.007 & $t$ & 0.010 & $t$ & 0.013 \\
\hline Unknown no. $7 *$ & 0.737 & 0.047 & 0.364 & $\ddagger$ & $\ddagger$ & $\ddagger$ & $\ddagger$ & 0.503 & 1.095 & $\ddagger$ \\
\hline Threonine & 0.479 & 0.152 & 0.136 & 0.219 & 0.210 & 0.177 & 0.199 & 0.327 & 0.298 & 0.227 \\
\hline Serine & 0.505 & 0.528 & 0.417 & $\ddagger$ & 0.308 & 0.308 & $\ddagger$ & 0.438 & 0.430 & 0.300 \\
\hline Asparagine & $<0.224$ & $<0.259$ & $<0.262$ & $<0.184$ & $<0.107$ & $<0.163$ & $<0.136$ & $<0.593$ & $<0.103$ & $<0.169$ \\
\hline Glutamine & 2.224 & $<4.733$ & $<1.153$ & $<5.856$ & 2.348 & 2.396 & 2.537 & 4.008 & 2.265 & 2.369 \\
\hline Proline & 0.014 & 0 & 0 & 0 & $t$ & 0.042 & 0.141 & 0 & 0 & 0.033 \\
\hline Glutamic acid & 0.075 & 0.085 & 2.373 & 0.018 & 0.044 & 0.049 & 0.015 & 0.116 & 0.030 & 0.016 \\
\hline Citrulline & $t$ & 0 & 0 & 0.030 & $t$ & 0.017 & 0.013 & & 0 & 0.022 \\
\hline Glycine & 0.150 & 0.092 & 0.078 & 0.124 & 0.060 & 0.060 & 0.093 & 0.080 & 0.059 & 0.095 \\
\hline Alanine & 0.324 & 0.302 & 0.180 & 0.294 & 0.272 & 0.283 & 0.413 & 0.443 & 0.298 & 0.278 \\
\hline$\alpha$-Amino- $n$-butyric acid & 0.009 & 0 & $t$ & $t$ & 0.034 & 0.048 & 0.044 & 0.047 & $t$ & 0.016 \\
\hline Valine & 0.142 & 0.112 & 0.119 & 0.128 & 0.173 & 0.172 & 0.222 & 0.237 & 0.109 & 0.107 \\
\hline Cystathionine & $t$ & 0 & $t$ & $t$ & $t$ & $t$ & 0 & & & \\
\hline Methionine & 0.027 & 0.035 & 0.023 & 0.035 & 0.021 & 0.028 & 0.024 & $\ddagger$ & 0.029 & 0.028 \\
\hline Isoleucine & 0.044 & 0.035 & 0.040 & 0.045 & 0.056 & 0.058 & 0.072 & 0.081 & 0.035 & 0.040 \\
\hline Leucine & 0.098 & 0.088 & 0.086 & 0.088 & 0.116 & 0.118 & 0.130 & 0.187 & 0.081 & 0.082 \\
\hline Tyrosine & 0.066 & 0.083 & 0.160 & $\ddagger$ & 0.111 & 0.123 & 0.112 & 0.117 & 0.048 & 0.068 \\
\hline Phenylalanine & 0.088 & 3.231 & 2.863 & 3.851 & 0.063 & 0.073 & 0.077 & 0.111 & 0.098 & 0.077 \\
\hline Unknown no. $8 *$ & 0.004 & 0 & 0 & 0 & 0.006 & 0.021 & 0 & 0.007 & 0 & 0 \\
\hline Ornithine & 0.038 & 0.080 & 0.035 & 0.112 & 0.071 & 0.045 & 0.040 & 0.082 & 0.060 & 0.080 \\
\hline Ethanolamine & 0.129 & 0.140 & 0.083 & 0.108 & 0.101 & 0.067 & 0.044 & 0.173 & 0.106 & 0.144 \\
\hline Lysine & 0.170 & 0.211 & 0.125 & 0.212 & 0.195 & 0.156 & 0.174 & 0.314 & 0.267 & 0.218 \\
\hline Histidine & 0.129 & 0.250 & 0.175 & $\ddagger$ & 0.094 & 0.094 & 0.103 & 0.126 & 0.119 & 0.126 \\
\hline Tryptophan & 0.014 & $\dot{8}$ & 8 & $\S$ & 8 & $\S$ & 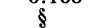 & 8 & 8 & $\$$ \\
\hline Enknown no. $9 *$ & 0.007 & 0.077 & 0.056 & 0.050 & $\stackrel{+}{\dagger}$ & 0.010 & 0 & 0.019 & 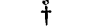 & 0.017 \\
\hline Arginine & 0.099 & 0.180 & 0 & 0.122 & 0.111 & 0.129 & 0.122 & 0.226 & 0.225 & 0.260 \\
\hline
\end{tabular}

* Calculated as leucine-equivalents.

† Present on chromatogram, but amount insufficient for quantitation.

$\$$ Present on chromatogram in measurable amount, but technical failure prevented quantitation.

are presented in Tables II, III and IV. Figures 1,2 and 3 present in graphic form the chromatographic analysis of one of the pooled specimens of normal CSF.

The following ninhydrin-positive substances were regularly found in the CSF of normal individuals and of the mental defectives studied: taurine, urea, aspartic acid, threonine, serine, asparagine, glutamine, glutamic acid, glycine, alanine, $\alpha$-amino- $n$-butyric acid, valine, methionine, isoleucine, leucine, tyrosine, phenylalanine, ornithine, ethanolamine, ammonia, lysine, histidine, and arginine. Found less frequently and usually in small amounts were citrulline and proline. Cystine, $\gamma$-amino-butyric acid and argininosuccinic acid were not detected in any CSF specimen. Tryptophan was not estimated in the chromatograms of the automatic amino acid analyzer, but was found in small amounts when searched for by the paper chromatographic technique described. In most CSF specimens a very small rise in absorbance was noted at the point where cystathionine is eluted from the $150-\mathrm{cm}$ column, just after the artifact produced on the chromatogram by the buffer change from $\mathrm{pH} 3.25$ to $\mathrm{pH} 4.25$. Whether or not this represents a trace of cystathionine in the CSF specimens studied is not clear.

In addition, six unidentified peaks were regularly encountered on the chromatograms of unhydrolyzed CSF, and two further unidentified peaks were noted in some specimens. Of the unidentified ninhydrin-positive substances regularly present in CSF, Unknown no. 1 emerged from the column at the position of phosphoserine and phosphothreonine, and Unknown no. 4 emerged at the position of phosphoethanolamine. In most CSF specimens prior to hydrolysis, and in all specimens after hydrolysis, an unexpected peak was encountered on chromatograms after urea and before aspartic acid. This substance, Unknown no. 6, was usually eluted from the $150-\mathrm{cm}$ column at 101 $\mathrm{ml}$ effluent volume in the $30^{\circ}$ to $50^{\circ} \mathrm{C}$ system, and was eluted at $91 \mathrm{ml}$ when the column was operated at $50^{\circ} \mathrm{C}$. In the same two systems, aspartic acid was usually eluted at 135 and at $110 \mathrm{ml}$, respectively. Unknown no. 6 had the same rate of travel on the column as the "erythro" form of $\beta$-hydroxyaspartic acid, and allo- $\gamma$-hydroxyglu- 
tamic acid. Unknown no. 8, present in some CSF specimens, was eluted from the $50-\mathrm{cm}$ column at the position of hydroxylysine, while Unknown no. 9 , present in all fluids studied, was eluted from this column at the position of carnosine.

Since asparagine and glutamine emerge from the column at the same effluent volume and give a combined peak on the chromatogram, values for these two amino acids were estimated from the increase in aspartic and glutamic acids, respectively, after acid hydrolysis of CSF. Serine was usually poorly separated, if at all, from asparagine and glutamine, and serine levels were therefore usually measured after hydrolysis.

After acid hydrolysis of CSF, the following changes were noted. Glutamic acid showed the greatest increase over the concentration found in the unhydrolyzed CSF, but there was also a marked increase in aspartic acid. Unknown no. 6 showed a three- to tenfold increase. The amount of glycine present was usually doubled. Methionine disappeared and was replaced by methionine sulfoxides. Urea was regularly decreased in amount. The values for alanine, $\alpha$-amino- $n$-butyric acid, valine, isoleucine, leucine, tyrosine and phenylalanine were not altered by hydrolysis, and cystine was found in no specimen following hydrolysis.

Finally, a large and highly variable amount of an additional unidentified ninhydrin-positive substance, Unknown no. 7, was found on chromatograms after hydrolysis. It was eluted from the column just before threonine at $50^{\circ} \mathrm{C}$ and just after serine at $30^{\circ}$ to $50^{\circ} \mathrm{C}$. This substance could not be detected in CSF prior to hydrolysis, possibly because of incomplete separation from serine, asparagine and glutamine. It was itself resistant to hydrolysis in $6 \mathrm{~N} \mathrm{HCl}$ at $110^{\circ} \mathrm{C}$ for 30 hours. It is presumed that this unidentified substance is an amino acid or an amino acid derivative, perhaps normally present in CSF, either partly or entirely, in a conjugated form.

It is likely that in most of the CSF specimens studied the marked increase in glutamic acid after hydrolysis could be accounted for entirely by the decomposition of glutamine. A possible exception

TABLE IV

A mino acid content of CSF of mental defectives (in $\mu$ moles $/ 10 \mathrm{ml}$ )

\begin{tabular}{|c|c|c|c|c|c|c|c|c|c|c|}
\hline \multirow[b]{2}{*}{ Amino acid } & \multirow{2}{*}{$\begin{array}{l}\text { Normal mean } \\
\text { (from Table II) }\end{array}$} & \multicolumn{3}{|c|}{ Hurler's syndrome } & \multicolumn{2}{|c|}{$\begin{array}{l}\text { Tuberous } \\
\text { sclerosis }\end{array}$} & \multicolumn{2}{|c|}{ Mongolism } & \multirow{2}{*}{$\begin{array}{c}\text { Schilder's } \\
\text { disease } \\
17\end{array}$} & \multirow{2}{*}{$\begin{array}{c}\text { Cerebro-oculo- } \\
\text { renal disease } \\
18\end{array}$} \\
\hline & & 10 & 11 & 12 & 13 & 14 & 15 & 16 & & \\
\hline Unknown no. $1^{*}$ & 0.025 & 0.022 & 0.013 & 0.018 & 0.024 & 0.022 & 0.024 & 0.022 & 0.017 & 0.007 \\
\hline Unknown no. $2^{*}$ & 0.033 & 0.017 & 0.008 & 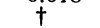 & 0.032 & $t$ & $t$ & 0.039 & 0.028 & 0.0 \\
\hline Unknown no. 3* & 0.038 & $t$ & $t$ & 0.012 & $\dagger$ & 0.022 & 0.032 & 0.028 & 0.018 & 0.009 \\
\hline Unknown no. $4^{*}$ & 0.053 & $0.02 ?$ & 0.036 & 0.030 & 0.036 & 0.060 & 0.085 & 0.037 & 0.037 & 0.040 \\
\hline Unknown no. 5* & $t$ & 0 & 0 & 0 & 0 & 0 & 0 & 0.066 & 0 & \\
\hline Taurine & 0.058 & 0.071 & 0.030 & 0.050 & 0.053 & 0.068 & 0.077 & 0.067 & 0.059 & 0.028 \\
\hline Urea & 26.35 & 22.00 & 16.00 & 29.30 & 26.34 & 31.30 & 29.20 & 29.72 & 39.14 & 42.60 \\
\hline Unknown no. 6* & 0.043 & 0.035 & 0.039 & 0.049 & 0 & 0.040 & 0.045 & 0 & 0 & 0.021 \\
\hline Aspartic acid & 0.031 & & & 0.004 & $t$ & 0.009 & 0.008 & 0.023 & $t$ & 0.015 \\
\hline Unknown no. $7 *$ & 0.737 & 0.726 & 1.399 & 0.350 & $\ddagger$ & 0 & 0.116 & $\ddagger$ & $\ddagger$ & 0.357 \\
\hline Threonine & 0.479 & 0.309 & 0.429 & 0.242 & 0.182 & 0.257 & 0.174 & 0.262 & 0.223 & 0.063 \\
\hline Serine & 0.505 & 0.363 & 0.398 & 0.259 & 0.418 & 0.343 & 0.378 & $\ddagger$ & $\ddagger$ & 0.201 \\
\hline Asparagine & $<0.224$ & $<0.136$ & $<0.129$ & $<0.017$ & $<0.235$ & $<0.127$ & $<0.265$ & $<0.096$ & $<0.150$ & $<0.165$ \\
\hline Glutamine & 2.224 & 2.996 & 3.002 & 3.100 & 1.508 & 2.315 & 3.068 & 1.454 & 2.932 & 2.440 \\
\hline Proline & 0.014 & 0 & 0 & 0 & 0 & 0 & 0 & $t$ & 0 & 0 \\
\hline Glutamic acid & 0.075 & 0.059 & 0.024 & 0.118 & 0.574 & 0.067 & 0.124 & 0.274 & 0.050 & 0.030 \\
\hline Citrulline & $t$ & 0.023 & 0.020 & & 0 & 0 & 0 & 0 & & \\
\hline Glycine & 0.150 & 0.066 & 0.074 & 0.053 & 0.043 & 0.076 & 0.056 & 0.111 & 0.070 & 0.110 \\
\hline Alanine & 0.324 & 0.175 & 0.232 & 0.214 & 0.184 & 0.170 & 0.250 & 0.252 & 0.280 & 0.228 \\
\hline$\alpha$-Amino- $n$-butyric acid & 0.009 & 0.014 & $t$ & 0.009 & $t$ & 0.015 & 0.010 & 0.022 & 0.030 & $t$ \\
\hline Valine & 0.142 & 0.119 & 0.099 & 0.096 & 0.103 & 0.098 & 0.144 & 0.156 & 0.185 & 0.118 \\
\hline Cystathionine & & & & 0 & 0 & & & & & \\
\hline Methionine & 0.027 & 0.044 & 0.030 & 0.020 & 0.018 & 0.020 & 0.022 & 0.028 & 0.030 & 0.014 \\
\hline Isoleucine & 0.044 & 0.036 & 0.031 & 0.031 & 0.035 & 0.035 & 0.049 & 0.054 & 0.052 & 0.049 \\
\hline Leucine & 0.098 & 0.083 & 0.065 & 0.072 & 0.088 & 0.082 & 0.120 & 0.130 & 0.118 & 0.088 \\
\hline Tyrosine & 0.066 & 0.056 & 0.054 & 0.059 & 0.085 & 0.078 & 0.084 & 0.082 & 0.094 & 0.046 \\
\hline Phenylalanine & 0.088 & 0.077 & 0.075 & 0.067 & 0.085 & 0.091 & 0.097 & 0.125 & 0.099 & 0.065 \\
\hline Unknown no. 8 & 0.004 & 0 & + & 0.011 & 0 & 0.007 & $t$ & 0 & 0 & 0 \\
\hline Ornithine & 0.038 & 0.025 & 0.059 & 0.085 & 0.063 & 0.077 & 0.06 .3 & 0.048 & 0.057 & 0.108 \\
\hline Ethanolamine & 0.129 & 0.082 & 0.086 & 0.107 & 0.061 & 0.205 & 0.179 & 0.046 & 0.061 & 0.132 \\
\hline Lysine & 0.170 & 0.069 & 0.163 & 0.145 & 0.104 & 0.165 & 0.228 & 0.181 & 0.130 & 0.185 \\
\hline Histidine & 0.129 & 0.137 & 0.165 & 0.151 & 0.097 & 0.093 & 0.111 & 0.098 & 0.110 & 0.095 \\
\hline Tryptophan & 0.014 & $\$$ & $\S$ & 8 & 8 & 8 & 8 & 8 & & \\
\hline Unknown no. 9 & 0.007 & $\stackrel{+}{t}$ & 0.034 & 0.028 & 0.035 & 0.017 & 0.036 & 0.029 & 0.020 & 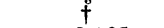 \\
\hline Arginine & 0.099 & 0.133 & 0.196 & 0.148 & 0 & 0.027 & 0.149 & 0 & 0.165 & 0.135 \\
\hline
\end{tabular}

* Cacluated as leucine-equivalents.

† Present on chromatogram, but amount insufficient for quantitation. + Present on chromatogram in measurable amount, but technical failure prevented quantitation. $\$$ Measurement not attempted. 

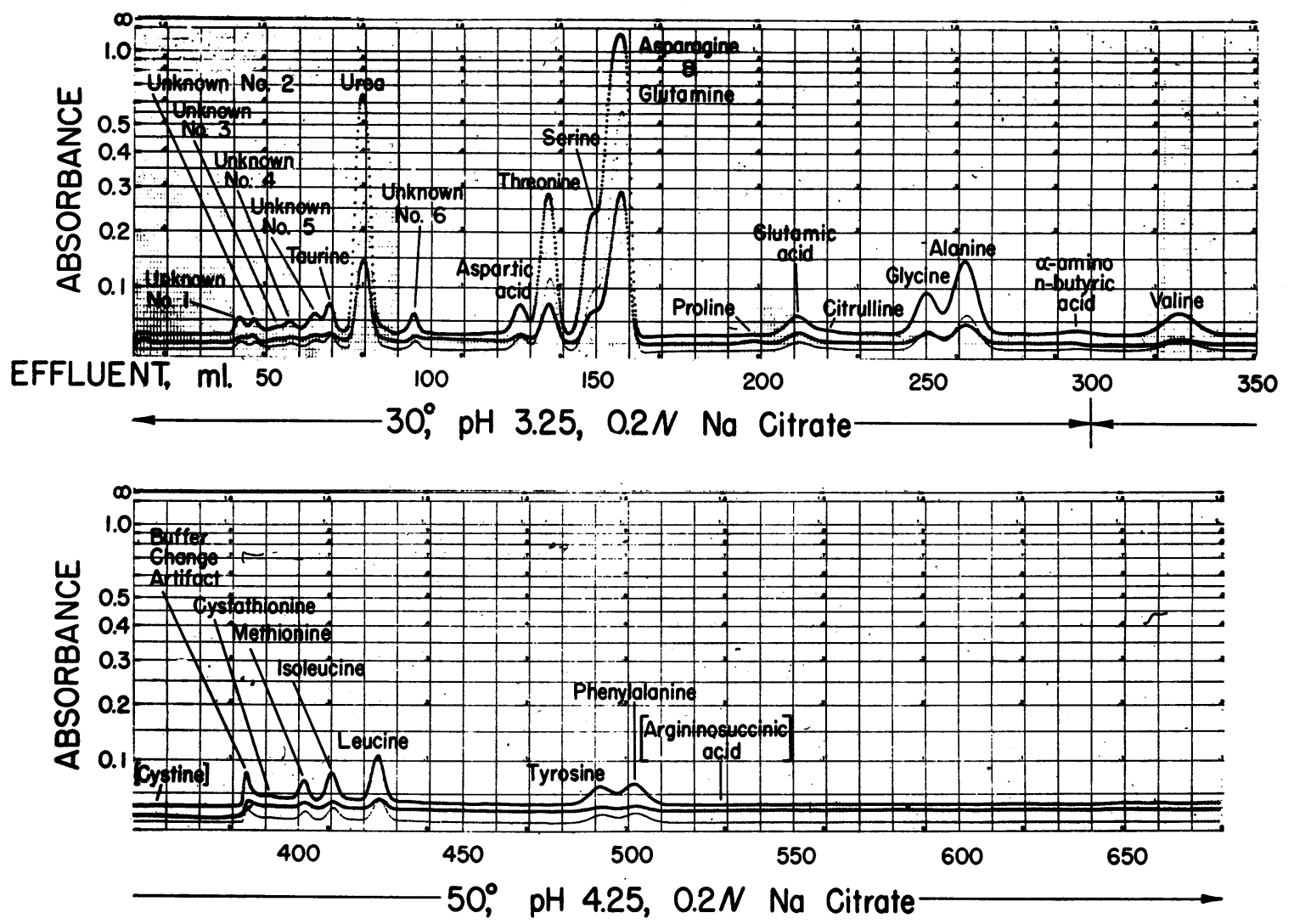

Fig. 1. Chromatographic analysis of amino acids and Related compounds in 10 mL of normal CSF applied to a 150-cm Column. Compounds enclosed in brackets were not detected in any specimens studied.

is the case of the CSF specimens from phenylketonurics, where the fluid may have contained phenylacetylglutamine, which on hydrolysis would release glutamic acid. The increase in aspartic acid, on the other hand, might result either from the hydrolysis of its corresponding amide, or from the hydrolysis of $\mathrm{N}$-acetylaspartic acid. This latter amino acid conjugate has been found in brain tissue in relatively high concentration (16), and might well be present in CSF. Since it is a ninhydrin-negative compound, it would not be detected in unhydrolyzed CSF. The values given for asparagine in Tables II, III and IV, therefore, are maximum values and may represent either asparagine or a combination of both compounds. The increase in glycine regularly noted following hydrolysis was probably due to the splitting of hippuric acid present in the CSF. The alssence of cystine and the failure of the $\alpha$-amino- $n$-butyric acid peak to increase after acid hydrolysis provicles evidence that glutathione and ophthalmic acid were absent from the CSF specimens studied.
In general the concentrations of amino acids present in the CSF of the eight forms of mental defect studied did not vary appreciably from those found in pooled CSF from normal adults. The only exception to this was the expected high concentration of phenylalanine found in the CSF of the three phenylketonuric patients. This ranged from 4.74 to $6.37 \mathrm{mg}$ per $100 \mathrm{ml}$ of CSF, and was similar to that found by Borek, Brecher, Jervis and Waelsch (12) using a microbiological method to determine phenylalanine in the CSF of phenylketonurics. The level of $\alpha$-amino- $n$-butyric acid was relatively high in the CSF of the three patients having Tay-Sachs disease, and two of these also showed appreciable amounts of proline, but the significance of these variations is doubtful.

\section{DISCUSSION}

The amino acid content of $\mathrm{CSF}$ as determined by other investigators is summarized in Table $\mathrm{V}$ and this is compared with that found in the present investigation. Proline, citrulline, asparagine 

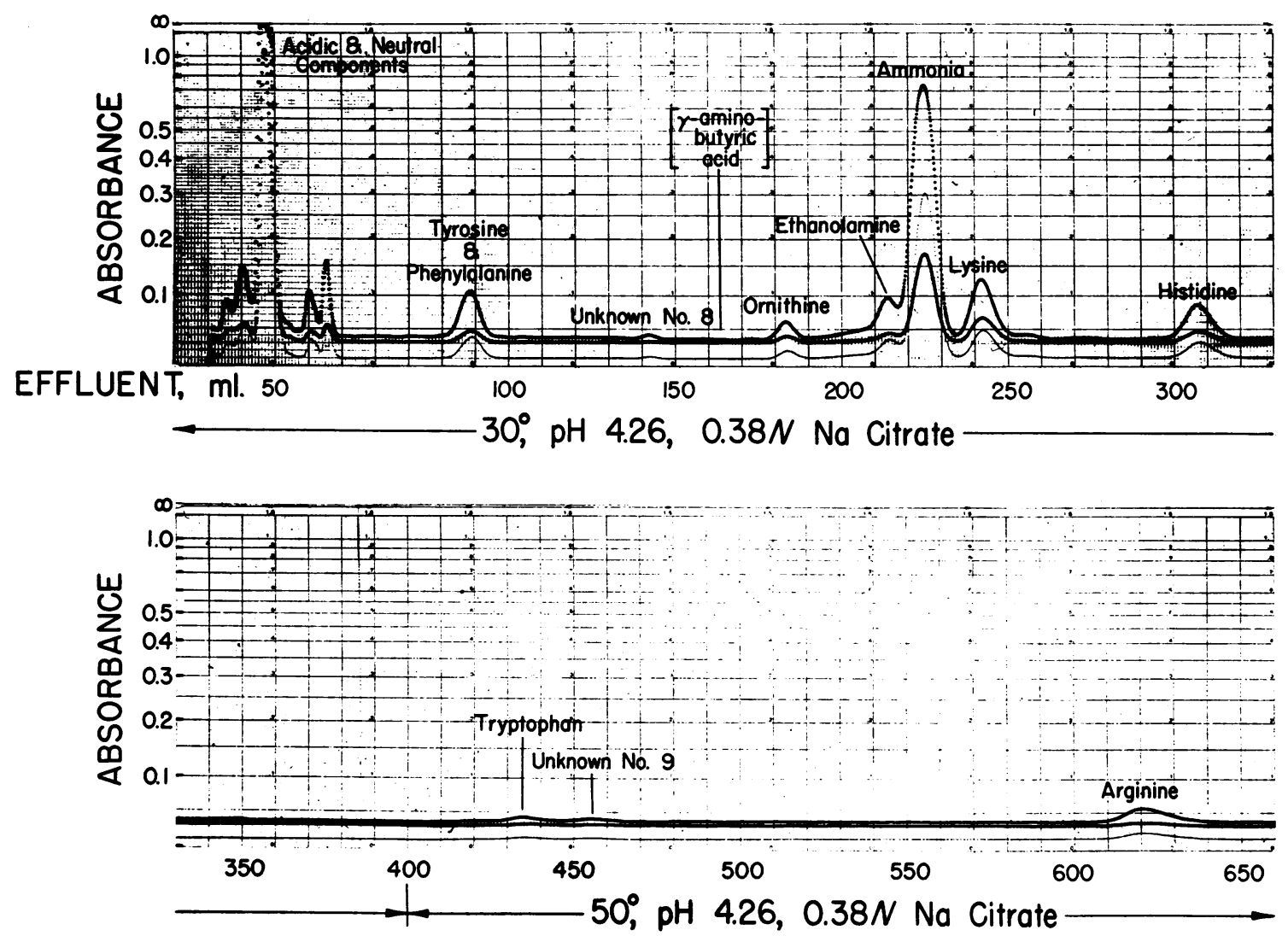

Fig. 2. Chromatographic analysis of amino acids and Related compounds in 10 mL of normal CSF applied to A 50-CM Column. $\gamma$-Aminobutyric acid was not detected in any specimen studied.

and cystathionine have not been previously reported as components of CSF. Walker and coworkers (4) found proline and methionine only in fluids which contained red blood cells. In the present study methionine was found in a measur- able amount in all except one CSF specimen, and in this fluid it was replaced by methionine sulfoxides. Proline and citrulline were found in a number of the fluids examined. It is apparent that these three amino acids are normal constituents

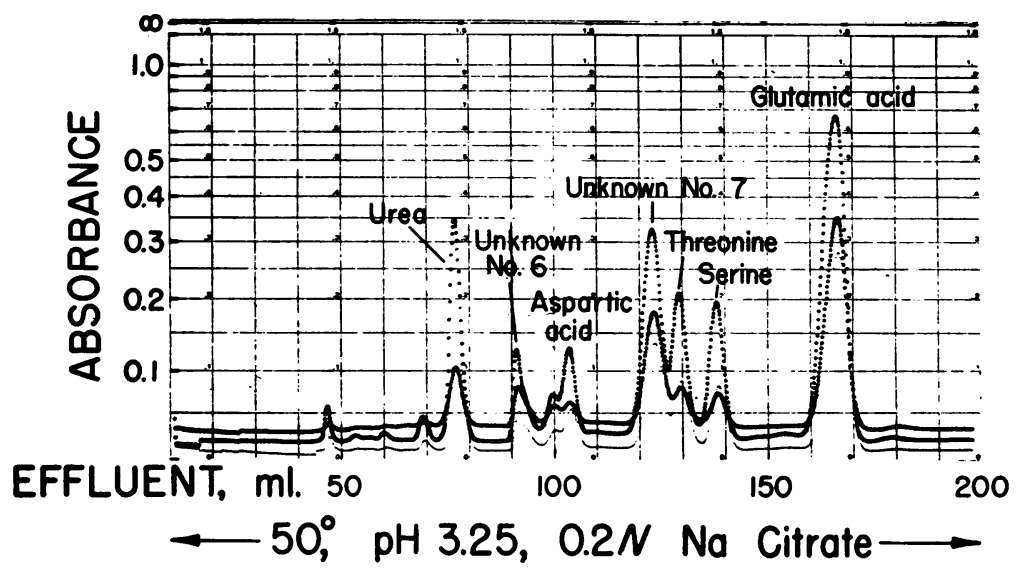

Fig. 3. Chromatographic analysis of amino acids and Related comPOUNDS IN 5 ML OF NORMAL CSF WHICH HAD BEEN HYDROLYZED WITH $2 \mathrm{~N}$ HCl For 2 HOURS AT $110^{\circ} \mathrm{C}$ Before application to a 150-CM COLUMN. 
of CSF. Asparagine is believed to be regularly present in CSF, but its identification is presumptive, being based on the increase in aspartic acid after hydrolysis. In any event, either asparagine or $\mathrm{N}$-acetylaspartic acid or both must normally be present in CSF.

Ornithine was found in each specimen of CSF in the present study, and there is evidence that it was not an artifact produced from the destruction of arginine during electrolytic desalting. Arginine was lost to a variable extent during desalting. In one pooled specimen of normal CSF, chromatography before and after desalting showed that although all of the arginine had been lost, there had been no concomitant increase in ornithine. The arginine values listed in Table II for normal CSF represent determinations on CSF which had not been desalted. Values for all other amino acids, and for arginine in the CSF of the 18 mentally defective patients, were determined on desalted fluids. Subsequent experiments have indicated that good chromatograms can be obtained without desalting, if the deproteinized CSF is first adjusted to $\mathrm{pH} 2.2$ with $\mathrm{HCl}$ before application to the column. Elimination of the desalting step in future studies of amino acids in CSF would avoid the partial or complete loss of arginine incurred in the present study.

Cystine was not found in any CSF specimen studied. It may be that cysteine and cystine were originally present in CSF, only to have been lost during storage at $-20^{\circ} \mathrm{C}$, or during the relatively slow deproteinization method used. Stein and Moore (17) have reported that the cystine content of plasma decreases during prolonged storage at $-20^{\circ} \mathrm{C}$, possibly as a result of oxidative formation of intermolecular bridges involving cysteine and the sulfhydryl groups of proteins. In future studies, immediate deproteinization of CSF with picric acid after its collection at lumbar puncture might lead to the detection of cystine.

$\gamma$-Aminobutyric acid was not detected in any CSF specimen. Although this amino acid has been reported as a normal constituent of CSF ( 5 , 11), Ludewig (18), using a paper chromatographic technique, was unable to detect it in fluids obtained from 26 patients suffering from various neurological diseases. Despite its relatively high concentration in brain tissue, $\gamma$-aminobutyric acid apparently is not present in detectable

TABLE V

Comparative study of amino acids in normal human CSF*

\begin{tabular}{|c|c|c|c|c|c|c|c|c|}
\hline $\begin{array}{l}\text { Authors } \\
\text { Reference no. }\end{array}$ & $\begin{array}{l}\text { Torre } \\
\text { et al. } \\
\text { (2) }\end{array}$ & $\begin{array}{l}\text { Porcellati } \\
\text { and Kemali } \\
(3)\end{array}$ & $\begin{array}{l}\text { Walker } \\
\text { et al. } \\
\text { (4) }\end{array}$ & $\begin{array}{l}\text { Logothetis } \\
(5)\end{array}$ & $\underset{(6)}{\operatorname{Huisman}}$ & $\begin{array}{c}\text { Knauff et al. } \\
(10,11)\end{array}$ & \multirow[b]{2}{*}{$\begin{array}{c}\text { Chemical } \\
\text { determination }\end{array}$} & \multirow[t]{3}{*}{$\begin{array}{l}\text { Present } \\
\text { study }\end{array}$} \\
\hline Method used & $\begin{array}{l}\text { Paper } \\
\text { chroma- } \\
\text { tography }\end{array}$ & $\begin{array}{l}\text { Paper } \\
\text { chroma- } \\
\text { tography }\end{array}$ & $\begin{array}{l}\text { Paper } \\
\text { chroma- } \\
\text { tography }\end{array}$ & $\begin{array}{l}\text { Paper } \\
\text { chroma- } \\
\text { tography }\end{array}$ & $\begin{array}{l}\text { Column } \\
\text { chroma- } \\
\text { tography }\end{array}$ & $\begin{array}{l}\text { Paper electro- } \\
\text { phoresis and } \\
\text { chromatography }\end{array}$ & & \\
\hline No. of subjects & 10 & & 26 & 52 & 1 pooled & 20 & 131 & \\
\hline $\begin{array}{l}\text { Alanine } \\
\alpha \text {-Amino- } n \text {-butyric acid }\end{array}$ & 0.08 & 0.84 & 0.11 & $\begin{array}{l}0.15 \\
0.02\end{array}$ & 0.15 & $t$ & & $\begin{array}{l}0.29 \\
0.01\end{array}$ \\
\hline$\gamma$-Aminobutyric acid & & & & 0.04 & & & & 01 \\
\hline $\begin{array}{l}\text { Arginine } \\
\text { Asparagine }\end{array}$ & 0.08 & & & 0.16 & 0.10 & $\dagger$ & & $\begin{array}{l}0.17 \\
0.30\end{array}$ \\
\hline Aspartic acid & & & 0.04 & 0.11 & 0.10 & $t$ & & 0.04 \\
\hline $\begin{array}{l}\text { Citrulline } \\
\text { Cystine }\end{array}$ & 0.21 & & & & 0.05 & & & $\frac{7}{8}$ \\
\hline Cystathionine & & & & & & 0.10 & & 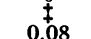 \\
\hline Glutamic acid & 1.04 & 1.22 & 0.06 & 0.09 & 3.35 & $t$ & & 0.11 \\
\hline Glutamine & & & 0.71 & 0.30 & & $t$ & 5 to 22 & 3.25 \\
\hline $\begin{array}{l}\text { Glycine } \\
\text { lat }\end{array}$ & 0.11 & 0.48 & 0.10 & 0.09 & 0.10 & $t$ & & 0.11 \\
\hline Histidine & 0.22 & & & & 0.05 & $t$ & & 0.20 \\
\hline Isoleucine & & & & & 0.05 & $\dot{t}$ & & 0.06 \\
\hline Leucine & 0.11 & 0.24 & 0.14 & 0.14 & 0.05 & $t$ & & 0.13 \\
\hline $\begin{array}{l}\text { Lysine } \\
\text { Methionine }\end{array}$ & & & & 0.17 & $\begin{array}{l}0.20 \\
0.05\end{array}$ & $t$ & & 0.25 \\
\hline Ornithine & & & & & & $t$ & & 0.05 \\
\hline Phenylalanine & 0.09 & 0.18 & 0.21 & 0.18 & 0.15 & $t$ & & 0.15 \\
\hline $\begin{array}{l}\text { Prolline } \\
\text { Serine }\end{array}$ & & & 0.16 & 0.22 & 0.10 & $t$ & & $\begin{array}{l}0.01 \\
0.53\end{array}$ \\
\hline Taurine & & & & & & & & 0.07 \\
\hline Threonine & & & 0.13 & 0.12 & 0.30 & $t$ & & 0.57 \\
\hline Tryptophan & 0.26 & & & & & 1 & & 0.03 \\
\hline Tyrosine & 0.11 & 0.22 & 0.08 & 0.16 & 0.10 & $t$ & & 0.12 \\
\hline Valine & 0.14 & 0.36 & 0.07 & 0.12 & 0.15 & $t$ & & 0.17 \\
\hline
\end{tabular}

* Values are expressed in $\mathrm{mg}$ per $100 \mathrm{ml} \mathrm{CSF}$, and except where indicated are mean values. $\dagger$ Substance present, but concentration not measured

\$ Present in trace amounts. 
amounts in CSF. It is also clear from the present study that argininosuccinic acid and glutathione are normally absent from CSF.

The finding of nine unidentified peaks on chromatograms of CSF had not been expected. One of these, Unknown no. 7, was usually present in relatively large amounts, and in a number of fluids exhibited an apparent concentration greater than that of serine and threonine. An unidentified ninhydrin-positive substance, emerging from the column of the amino acid analyzer at the same point as Unknown no. 6 in the present study, has been noted by Moore, Tallan and Stein in human blood plasma, liver and brain extracts $(19,20)$. Further studies are planned to attempt identification of these unknown compounds.

The relative concentrations of the various amino acids in CSF and in postabsorptive plasma in normal adults are compared in Table VI. The data for plasma $(17,21)$ were obtained by a column chromatographic technique similar to that employed in this study for the quantitation of amino acids in CSF. It will be noted that glutamine is the predominant amino acid both in plasma and in CSF. Most of the amino acids present in CSF occur in concentrations only 5 to 15 per cent of those found in plasma. In the case of proline, the disparity between CSF and plasma levels is much more marked. On the other hand, glutamine, asparagine, serine and threonine occur in CSF in close to one-half their concentration in plasma. Aspartic acid levels are about equal between the two fluids. Ethanolamine is present in greater concentration in the CSF than in plasma. This would suggest that the CSF is not a simple mirror of conditions prevailing in the blood stream, but also reflects in part the chemical milieu of the brain.

Although the measurement of amino acid concentrations in the CSF of several genetically determined diseases in this study failed to provide clues to the mechanism of the mental defect characteristic of each disease, this approach may be worth applying to other neurological disorders. When patients become available, it would be of interest to measure amino acid concentrations in the CSF in conditions such as maple syrup urine disease and cystathioninuria. In the former condition, it is anticipated that CSF concentrations of leucine, isoleucine, valine and methionine will be
TABLE VI

Relative concentration of amino acids in normal adult human plasma and CSF*

\begin{tabular}{lcc}
\hline \multicolumn{1}{c}{$\begin{array}{c}\text { Amino acid (or related } \\
\text { compound) }\end{array}$} & $\begin{array}{c}\text { Plasma } \\
(17,21)\end{array}$ & CSF \\
\hline Alanine & 3.41 & 0.29 \\
$\alpha$-Amino- $n$-butyric acid & 0.30 & 0.01 \\
Arginine & 1.51 & 0.17 \\
Asparagine & 0.58 & 0.30 \\
Aspartic acid & 0.03 & 0.04 \\
Citrulline & 0.50 & $\dagger$ \\
Cystathionine & & $\dagger$ \\
Cysteine & 0.40 & $\ddagger$ \\
Cystine & 1.00 & $\ddagger$ \\
Ethanolamine & & 0.08 \\
Glutamic acid & 0.70 & 0.11 \\
Glutamine & 8.30 & 3.25 \\
Glycine & 1.54 & 0.11 \\
Histidine & 1.15 & 0.20 \\
Isoleucine & 0.89 & 0.06 \\
Leucine & 1.69 & 0.13 \\
Lysine & 2.72 & 0.25 \\
Methionine & 0.38 & 0.04 \\
1-Methylhistidine & 0.11 & \\
3-Methylhistidine & 0.08 & \\
Ornithine & 0.72 & 0.05 \\
Phenylalanine & 0.84 & 0.15 \\
Proline & 2.36 & 0.01 \\
Serine & 1.12 & 0.53 \\
Taurine & 0.55 & 0.07 \\
Threonine & 1.39 & 0.57 \\
Tryptophan & 1.11 & 0.03 \\
Tyrosine & 1.03 & 0.12 \\
Valine & 2.88 & 0.17 \\
& & \\
& &
\end{tabular}

* Mean values expressed in $\mathrm{mg}$ per $100 \mathrm{ml}$ plasma or CSF. $\dagger$ Present in trace amounts.

$\ddagger$ Cysteine and cystine not determined.

found to be elevated for the same reason that phenylalanine has been found elevated in the CSF of phenylketonurics. In the latter condition, the finding of a larger amount of cystathionine in CSF than in the plasma would help to localize the site of the metabolic error. At the same time, it must be realized that the failure to detect unusual amino acid concentrations in CSF does not eliminate the possibility that a given form of mental defect may be caused by deranged cerebral amino acid metabolism; for the amino acid in question may, like $\gamma$-aminobutyric acid, fail to accumulate in the CSF in spite of a high concentration in brain tissue.

\section{SUM MARY}

Concentrations of amino acids have been determined in pooled normal human cerebrospinal fluid (CSF) using the automatic amino acid analyzer. These have been compared with values obtained by other investigators using different techniques, as well as with the concentrations of amino acids found in human postabsorptive plasma. 
Twenty-two amino acids were regularly present in CSF, and three others were sometimes present. Cystine and $\gamma$-aminobutyric acid, which have been reported as constituents of CSF, were not detected. Seven unidentified ninhydrin-positive substances were regularly found in CSF, one of them in relatively large amounts.

Amino acid concentrations were similarly measured in the CSF of patients having genetically determined diseases characterized by mental defect. These disorders included phenylketonuria, TaySachs disease, Hurler's syndrome, Huntington's chorea, tuberous sclerosis, mongolism, Schilder's disease, and the cerebro-oculo-renal disease of Lowe. Except for the finding of greatly elevated concentrations of phenylalanine in the CSF of the phenylketonurics studied, there were no significant deviations in these patients from the amino acid concentrations found in pooled normal CSF. The possible usefulness of applying this technique to other neurological disorders is discussed.

\section{ACKNOWLEDGMENTS}

The authors are indebted to Dorothy Walker, Jean Cormack, and Beverly Kaufman for valuable technical assistance. The normal CSF was graciously collected by Dr. Jack Hallett of the Kaiser Foundation Hospital, Los Angeles, and the CSF from patients having TaySachs disease by Dr. Alfred Knudson of the City of Hope Medical Center, Duarte. The authors wish to thank Dr. H. J. Sallach of the University of Wisconsin Medical School for supplying a sample of $\beta$-hydroxyaspartic acid, and Dr. Milton Winitz of the National Cancer Institute for supplying samples of the diastereoisomers of $\gamma$-hydroxyglutamic acid. The authors also gratefully acknowledge helpful suggestions from Dr. Stanford Moore of the Rockefeller Institute, and from Professor Linus Pauling, Dr. Walter A. Schroeder, and Dr. Kenneth N. F. Shaw.

\section{REFERENCES}

1. Allan, J. D., Cusworth, D. C., Dent, C. E., and Wilson, V. K. A disease, probably hereditary, characterised by severe mental deficiency and a constant gross abnormality of aminoacid metabolism. Lancet $1958,1,182$.

2. Torre, M., Scarzella, R., and Zanalda, A. Ricerca cromatografica con dati quantitativi degli aminoacidi liberi del liquor di sossetti normali. Boll. Soc. ital. Biol. sper. 1953, 29, 196.

3. Porcellati, G., and Kemali, D. Report of the free amino acids in spinal fluid. G. biochim. 1954, 21-24, 488.

4. Walker, B. S., Telles, N. C., and Pastore, E. J. Amino acids of the cerebrospinal fluid; normal paper chromatographic pattern and its duplication in multiple sclerosis. A. M. A. Arch. Neurol. Psychiat. 1955, 73, 149.

5. Logothetis, J. Free amino acid content of cerebrospinal fluid in humans and dogs. Neurology 1958, 8, 299.

6. Huisman, T. H. J. Concentration of various amino acids in cerebrospinal fluid. Ned. T. Geneesk. 1955, 99, 3357.

7. Whitehead, T. P., and Whittaker, S. R. F. A method for the determination of glutamine in cerebrospinal fluid and the results in hepatic coma. J. clin. Path. 1955, 8, 81.

8. Walshe, J. M. Glutamic acid in hepatic coma. Lancet $1955,1,1235$.

9. Gilon, E., Szeinberg, A., Tauman, G., and Bodonyi, E. Glutamine estimation in cerebrospinal fluid in cases of liver cirrhosis and hepatic coma. J. Lab. clin. Med. 1959, 53, 714.

10. Knauff, H. G., and Zickgraf, H. Über das Vorkommen von freiem Äthanolamin (Colamin) im Liquor cerebrospinalis des Menschen. Hoppe-Seylers Z. physiol. Chem. 1958, 312, 264.

11. Knauff, H. G., Mialkowsky, W., and Zickgraf, H. Über die freien Aminosäuren des Liquor cerebrospinalis und ihren Nachweis mit kombinierten papierchromatographischen und elektropherographischen Methoden. Z. klin. Med. 1959, 155, 483.

12. Borek, E., Brecher, A., Jervis, G. A., and Waelsch, H. Oligophrenia phenylpyruvica. II. Constancy of the metabolic error. Proc. Soc. exp. Biol. (N. Y.) $1950,75,86$

13. Logothetis, J. Cerebrospinal fluid free amino acids in neurologic diseases; observations in aspartic acid concentrations. Neurology 1958, 8, 374.

14. Spackman, D. H., Stein, W. H., and Moore, S. Automatic recording apparatus for use in the chromatography of amino acids. Analyt. Chem. 1958, 30, 1190.

15. Lowe, C. U., Terrey, M., and MacLachlan, E. A. Organic-aciduria, decreased renal ammonia production, hydrophthalmos, and mental retardation; clinical entity. Amer. J. dis. Child. 1952, 83, 164.

16. Tallan, H. H., Moore, S., and Stein, W. H. N-acetyl$l$-aspartic acid in brain. J. biol. Chem. 1956, 219, 257.

17. Stein, W. H., and Moore, S. The free amino acids of human blood plasma. J. biol. Chem. 1954, 211, 915.

18. Ludewig, S. Glutamine, glutamic acid, and $\gamma$-aminobutyric acid in cerebrospinal fluids. A. M. A. Arch. Neurol. Psychiat. 1953, 70, 268.

19. Moore, S. Personal communication.

20. Tallan, H. H., Moore, S., and Stein, W. H. L-Cystathionine in human brain. J. biol. Chem. 1958, 230, 707.

21. Brigham, M. P., Stein, W. H., and Moore, S. The concentrations of cysteine and cystine in human blood plasma. J. clin. Invest. 1960, 39, 1633. 